\title{
A Brief Discourse about Cultural Innovation of University Spirit
}

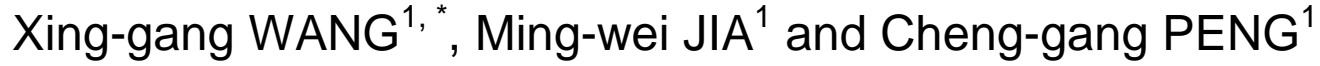 \\ ${ }^{1}$ Wuhan University of Technology, China
}

Keywords: University spirit, Cultural innovation, Openness, Inclusive, Put people first, Perfection.

\begin{abstract}
As the important vein and foundation for development and survival of university, culture is a necessary mark and feature that distinguishes a university from one another. The function of university can not be fully played without culture's nourishing and nurture, which is also the nature and soul of university. This paper elaborates the view from four aspects: inwardly, university should be active and open to show the universities' era property; in work, university should be inclusive and absorb anything and everything to create a harmonious atmosphere; in ideology, universities should put people first to firmly grasp the developing idea; in setting goals, university should pursue excellence to establish university of perfection.
\end{abstract}

\section{Introduction}

Cultural Innovation is a basic proposition, which is worth serious pondering and being put into practice by scholars at all times. In some way, the history of university development is also the history of cultural innovation. Currently, the higher education in China has just entered a key turning stage featured by "Deepening the reform and connotation development", which requires overall growth of education quality and cooperative innovation capability. In this stage, our universities still do not do well enough to meet the social demands and people's expectations in enhancing the cultural quality, constructing cultural atmosphere, bringing into play culture's educating function, improving students' cultural quality, etc. And it has been the prominent problem affecting and restricting strengthening educational quality in our China. Therefore, the important missions for Chinese universities nowadays are, holding high the "great banner of socialism with Chinese characteristics", to greatly enhance ideals, initially undertake the duty of realizing cultural inheritance and innovation, develop advanced culture, lead the social climate, so as to play the culture's educational function and contribute our efforts to enhancing the cultural soft power of our country as well as the Chinese international cultural influence.

\section{Open Freely to Show the Era Property of Universities}

University is a completely open system to the society, for which openness is the essential attribute. American Universities are now in leading position in education of the whole world, which are remarkably featured by openness. The openness not only promotes it's own thriving development, but also contributes to stimulating American economy prosperity and social progress.In a free era and international environment, modern universities should undertake the duty and mission to promote the development of teachers and students as well as the society, which demands the universities to get involved in the big free environment and initially join in the process of social development. From the external part of university, the openness of university covers the open and exchange to the world, the open and service to economy and society; from 
the university itself, the openness of university is obviously reflected in the thoughts and ideals of running schools, facing the modernization, the world and the future, involving education resources into the society, constructing open talent cultivation system, science and research system, social service system and cultural inheritance and innovation system. In the age of globalization, international cultures are interactional. None of these cultures can exist alone detached from the international cultures. Only if Chinese culture gets in exchange with international cultures can it strongly influence the whole world. University must make efforts to build our national image and improve Chinese cultural influence and vitality. We must clearly understand university duties, make reasonable strategies in university development, greatly stimulate innovation in ideals, systems and management and fully play university's function of talent cultivation, scientific research and cultural inheritance and innovation with open mind, conscientious attitude and self-confidence; we should furtherly improve university's internal management structure and actively promote information publicity and democratic administration to build up an open and democratic administrative pattern; we should innovate the mechanism by effectively integrating scientific growing resources to construct a collaborative innovation platform for politics, industry, research and application, whose fundamental forms include cooperation between local governments and university, between different universities, between university and enterprises, between schoolfellows, between universities at home and abroad. Thus, the driving force and dynamism of university development are improved to stimulate the positive interaction between the university and society. We should strengthen the construction of culture carriers such as Confucius Institutes, support various national academic groups and artistic and sports groups to play a constructive role in the international cultural exchange and promotion of Chinese culture. We should encourage our teachers and researchers to launch researches in culture to advance our culture industry and provide cultural achievements of university level and professional characteristics. Only by sticking to expanding openness can university timely get abundant information, constantly carry forward the knowledge updating, widen the teachers' and students' vision and break trough the limit of traditional ideals to adequately mobilize and make use of internal and external resources in the university. So, university can get broader path for its development to better transfer scientific technology into practical productivity, thus providing firm material foundation for cultural construction.

\section{Absorb Anything and Everything to Create a Harmonious Atmosphere in University}

As an old saying goes, "The sea can hold the water from thousands of rivers, it's big because of its capacity", tolerance is not only an individual conduct and temperament, but also an art, a unity of diversity and uniformity. The most precious feature of university or master is their tolerance for everything. As an important base for cultural innovation and transmission as well as a necessary stage in public education, university should adopt inclusive developing concept, carry forward the inclusive tradition of Chinese culture, actively communicate with various cultures and absorb and use fruits of all excellent cultures for reference according to the demands in building a powerful socialist country. Thus, university will make great contributions to a new boom of Chinese culture. University should welcome different schools, different academic thoughts, bright younger generations as well as other people's success and tolerate the 
frustration or failure, which is the objective demand for creating a university environment and atmosphere of high level. Talents and masters can be nurtured only in this environment and atmosphere. In addition, we should provide space for communication and conversation to have various cultural forms exchange, communicate and even compete with each other. Through this process, these cultural forms will find new direction and amalgamations and eventually figure out the truth. Instead of staying in the level of people's value and interaction, university tolerance must be transferred into community's social acts and positive policy, which will lead and accelerate the form of all-inclusive cultural atmosphere by shaping the community consciousness of confidence and tolerance. With the goal of development, equal participation and sharing growth should be greatly stressed. The social value and positive meaning of tolerance can be shown only if all the teachers, students and staff initiatively and equally participate in the university building and share the achievements together. In aspect of policy leading, we should implement the guideline of "Let all the flowers bloom and all the schools of thought contented" and stick to "Serve the people and socialism" to ensure the advancing direction of our culture. In establishing the related institution, positive institution should be applied to protect the smooth operation in the university. Positive and effective institution's essence lies in its advocating of growing equal opportunities, and its core lies in justice and efficiency with its goal of ensuring the whole staff's participating in the university construction and enjoying the happiness brought by the achievements. On the other hand, while creating the atmosphere, we should spare no effort to build a confident, tolerant and generous environment and internalize the tolerance idea of university into behavioral consciousness in administration, culture, academy and interpersonal communication, so as to sublime the tolerance idea to university campus culture. Many Chinese universities are of super large scale because of mergence and adjustment, and it's inevitable for them to come across various problems. Leaders at every level and all the staff in university ought to attach great importance to their education career and try to understand and practice tolerance to constantly enhance university campus tolerance and improve university cultural soft power, so as to create a harmonious campus environment and spiritual atmosphere. By doing this, our will for fight and courage can be improved, our thoughts and conduction can be wiser and our administration and institution can be more scientific for our better performing our duty and mission entrusted to us by our education career.

\section{Put people first to firmly grasp the Developing idea}

Putting people first is the core of scientific outlook on development with people-oriented idea as its fundamental idea. Humanistic love is the best interpretation for people-oriented idea. In the process from coming into being to developing, modern universities always firmly stick to the basic function of talents cultivation. The demands for talents cultivation generating from different historical periods, different ruling classes and different social development together constitute the shared and fundamental task for universities. The people-oriented idea on campus is the idea for exploring new knowledge, transmitting civilization and nurturing talents and making them serve the society in return in the university. For young students, university people-oriented idea is an education philosophy fully respecting the personality and character of the education receivers and paying much attention to the receivers' initiative, comprehensiveness and difference to develop their potential. For the teachers and staff, university 
people-oriented idea fully reflects and honors every staff's individual value by promoting their position in education activities to completely inspire their initiative and creativity as well as adequately considering their interests. For the people-oriented management, teachers, students and all the other staff are precious wealth of the university, the masters of the university as well as most important key resources, so the main principle in the management should reflect the inter-subjectivity. Under this managing pattern, both teachers and students are subjects, especially the students, who are not only the objects of management, but also the participators in managing and supervising. The governors and ordinary staff in the university are cooperators with each other, but not just higher levels and lower levels as that in traditional pattern. So the governors should encourage the other staff to seriously think over their job, and form an initial operation process from the staff to the governors. The main duty of university governors is to reintegrate and optimize the organization structure and improve the system to make every staff enjoy rights as well as perform duties. Therefore, all the staff's real and potential productivity can be accelerated and the coordination in the development between people and educational career can be over-all planned. With rapid development of society and swift updating of knowledge, talents are now the decisive factor in university's growth and development. In order to stand still in the competition in the society in future, it's necessary for university to develop its talents resources, and continuously increase investment in that. Meanwhile, it's also of great importance to reflect its humanistic love through being considerate to the students. University should attach more importance to taking care of the university staff and students' development and demands to deeply improve the respect for the staff and students as well as for academic freedom. According to the people-oriented idea, firstly, we should seriously consider the problems in management, service and working style caused by lack of sticking to putting people first; secondly, we should properly deal with various relationship like the relationship between the governors and staff, the relationship between management and service; thirdly, we should stably set up the awareness of serving teachers and students and serving for nurturing talents; fourthly, we should respect, understand and care every staff with considering and dealing with affairs from their perspective and make it the governors' political responsibility and duty to focus on and improve people's livelihood. According to the people-oriented idea, in our cultural construction, we should be close to practice, real life and our staff to have them play their function of subject. What's more, we need to insist that the culture development benefit the teachers and the students and rely on them as well. We must try our best to promote overall development of people to cultivate the socialistic citizens to be ambitious, moral, educated, and disciplined.

\section{Pursue Excellence to Establish University of Perfection}

Another old saying goes, "What the great learning teaches, is to illustrate illustrious virtue; to renovate the people; and to rest in the highest excellence." "Being perfect" is always the ultimate goal for Chinese culture, and the value pursuit for realizing people' s over-all development. "To rest in the highest excellence" is a pursuit whose core lies in being excellence for highest state, sublimation from selfhood state to anatman state, and a reflection of true sincerity, true love, true honesty and true wisdom. With the great scale expansion in higher education today, pragmatism defeats the bottom line of some universities. The phenomenon of utilitarianism is common in some universities and much corruption in the society has their epitome in some universities. In the expansion 
from elite education to public education, Chinese universities get lost in the rapid development. Higher education experts sharply criticized the phenomenon"university just focuses on the market". The marketization of university makes market overwhelm culture building in university; and the officialdomization in university also makes the officialdom overwhelm culture building in university. Currently, our country is in a critical period in constructing an all-round well-off society and in the key stage of accelerating economic development mode transformation, social economic advancement takes on different characters of a new stage, and profound changes also take place in the global world. As our comprehensive power has increased a lot, China's development road has been recognized by the international society. Consequently, Chinese universities get more attention from the international society than ever before, thus leading the Chinese universities' participation in the competitions with other international universities. On one hand, China has put forward the goal of building several world-class universities and a good number of high-level universities. Correspondingly, many domestic universities have presented first-class goals for various subjects and aspects while some other universities hope to get more support from the country to construct high-level universities and famous universities, thus causing fiercer and fiercer competitions for the resources among the domestic universities especially the key universities. On the other hand, domestic universities actively take part in the rivalries in higher education in the whole world, in which some prestigious universities eagerly need some ultra-convention development to catch up with the world-class universities. These rivalries are about numbers of aspects such as talents, scientific research, culture and so on, which is an omnidirectional competition involving realization of national strategies with the nature of rivalries in national culture. As an important carrier of excellent cultural inheritance and key source of ideological and cultural innovation, our universities can only gradually accumulate experience and obtain advantages in the rivalries through continuously keeping forging ahead, blazing new trails, going beyond ourselves and going for the perfect. As a result, our national cultural soft power and international influence will be strengthened to contribute to accelerating the advancement of human civilization. Universities should pursue "being perfect" in education and firmly stick to the idea of "excellent education". In order to build up universities appealing to the public and stick to intrinsic development with promoting teaching quality as its core, universities ought to apply more energy and resources to improving students' quality, building teachers teams of high quality, increasing the levels in nurturing talents and enhancing the capability in scientific research. Universities are demanded to be enthusiastic about science and devoted to academy as well as innovate bravely to constantly enhance the level of academic research and achieve high-level academic fruits, eventually creating a full-bodied academic atmosphere on campus. At last but not least, universities should advocate and pursue perfect ethics, stably stick to socialist ethics and seriously observe code of ethics and law of the society to cultivate talents with pure ideology, noble sentiment and ideal pursuit.

\section{Acknowledgement}

This research was financially supported by "the Fundamental Research Funds for the Central Universities(WUT:131357003)", "Hubei Province Department of Education project 'Research on the Combination of Professional Education and Entrepreneurship Education'(Number: 20152s0061)" and "Hubei Province Department of Education 
project 'Research on the Influence of Quality Education on the Improvement of College Students' Entrepreneurial Ability'(Number:20152s0063)”.

\section{References}

[1] Chen Li-Yun, Yan Shi-Yun. Embodiment of "harmony" in the concept of well-being of China.[J]. Zhonghua Yishi Zazhi, 2010, 40(5).

[2] Peizhi SHI, Qing YAO University Soft Power: Meaning and Strategy of Construction from the Perspective of "Harmony" Culture. International Business and Management, 2011, Vol.3 (2), pp.92-98

[3] Shi Yigong, Rao Yi. China's research culture.[J]. Science, 2010, 329(5996).

[4] Lv Xuemei.Analyze the Function of Social Practice of Chinese University Student from the View of Character Education.Proceedings of 2012 International Conference on Education Reform and Management Innovation(ERMI 2012) Volume 3.2012

[5] Xing-guo Xiong,Hong-juan Zhu. Promotion of the Construction of Scientific and Technological Cultures on Campus of Colleges and Universities[A]. Lecture Notes in Management Science 2011 International Conference on Physical Education and Society Management (ICPESM2011 2011 V1)[C]. 2011

[6] Lihua Cui, Shuhua Li. On College Students' Humanistic Quality Based on Freud's Personality Structure Theory [A]. Proceedings of the 2015 Northeast Asia International Symposium on Linguistics, Literature and Teaching [C]. 2015

[7] Luquan Zhang. Problems in the Ideological and Political Education in Contemporary Colleges and Their Countermeasures [A]. Proceedings of the 2011 2nd Asia-Pacific Conference on Wearable Computing Systems (APWCS 2011) and 2011 International Conference on Intelligent Control and Information Technology (ICICIT 2011 V4)[C]. 2011 